\title{
ADMINISTRATIVE AND LEGAL REGULATION OF INFORMATION RELATIONS OF PUBLIC PROCUREMENTS SUBJECTS IN THE ECONOMIC SPHERE
}

\author{
Mykhailo Vilhushynskyi ${ }^{1}$, Andrii Chornous ${ }^{2}$
}

\begin{abstract}
The purpose of the article is to scrutinize administrative and legal regulation of information relations of public procurement subjects in the economic sphere. Within the framework of the conducted research, the authors note that the system of subjects that carry out administrative and legal regulation of information relations in public procurement consists of general and special public administration subjects. The primary objectives of the article are the following: 1 ) to determine an exclusive list of public administration subjects that provide administrative and legal regulation of information relations in the field of public procurement; 2) to outline major trends of further development of administrative and legal regulation that relates to information relations of public procurement subjects. Methodology. In the course of the article preparation, a set of philosophical and ideological approaches has been used (in particular, the dialectical approach, which is a way of thinking based on the analysis of all available views on disclosure of the content of administrative and legal regulation of information relations of public procurement subjects; analytical approach, which is based on cognitive activity concerning proving or refuting the notion of a public procurement subjects system; hermeneutic that is used to understand the terms related to information relations of public procurement subjects in the economy); general scientific research methods (logical, which is based on "simple to complex" and "abstract to concrete" principles and relates to general characterization of information relations of public procurement subjects in the economic field); special methods (system-structural method when defining organizational structure and legal regulation of public procurement subjects activity, legal comparative analysis when studying foreign countries expertise; formal legal and formal logical approaches). Results. According to the results of the research, the authors have classified all public administration subjects that carry out legal administration of information relations in the field of public procurement into four separate organizational and structural levels. The particular article provides authors' assumptions concerning further development of administrative and legal regulation of information relations of public procurement subjects in the economy, namely, emphasizes the necessity of strengthening preventive control in forms of general (analytical) monitoring, supervision of individual procurement procedures, and further automation of procurement processes; accentuates the tendency of public procurement sphere professionalization by organizing personnel trainings and educating public officials how to work with advanced information technologies; supports the need to continue implementing measures aimed at improving legislation, professionalizing labour resources in the public procurement field, improving international relations, attracting additional investments to integrate advanced technologies and hire field experts with background in managing national information resources and building e-government. Practical implications. The authors'survey results may be used in legislative work related to the legal regulation of information relations of public procurement subjects in the economy. The particular article may also be used in further scientific researches concerning information relations of public procurement subjects in the economic field. Moreover, the article might be used in the academic process, in lectures and seminars on information and administrative law. Value/originality. The scientific novelty of the article comprises of synthesis of existing normative and doctrinal approaches to understanding information relations of public procurement subjects in the economy; generalization of information concerning public procurement subjects in the economic field; determination of development prospects of administrative and legal regulation of information relations of public procurement subjects in the economic sphere. The authors have articulated development prospects of administrative and legal regulation of information relations of public procurement subjects in the economy, emphasized the necessity of enhancing
\end{abstract}

\footnotetext{
Corresponding author:

${ }^{1}$ Taras Shevchenko National University of Kyiv, Ukraine.

E-mail: m.vilgushynskyi@ukr.net

2 Taras Shevchenko National University of Kyiv, Ukraine.
} 
preventive control in the form of general (analytical) monitoring, particular procurement procedures supervision, and further automation of the procurement process. Moreover, the article focuses on the professionalization of the public procurement sphere through educating qualified personnel to work with modern information systems and technical devices. The authors also support the necessity of continuing the implementation of measures aimed at the legislation improvement, public procurement sphere professionalization, international relations development and proper executions of functions established by the Law of Ukraine "On Public Procurement".

Key words: economy, public procurement, information relations, information infrastructure, administrative and legal regulation of national information infrastructure.

JEL Classification: K23, H57

\section{Introduction}

Modern European integration and globalization processes in Ukraine are accompanied by drastic changes in all spheres of public life, including economic ones. Ukraine, like any other state, constantly faces the problem of public funds rational usage: in order to reduce expenditures and direct cash flows in more efficient way to meet the citizens needs and ensure proper functioning of the state mechanism, to support and enhance economic development, which will enable Ukraine to become a full-fledged entity on the international arena. The institute, which is called upon to implement the above components, is public procurement.

It should be noted that public procurement is not only a purely economic process but also the authorized public administration authorities' activity process, which is based on legal norms according to which the public procurement of goods, works, and services takes place. Accordingly, taking into account the public (administrative) component of public procurements, it is expedient to examine possible issues related to administrative and legal regulation of information relations of public procurement entities in the economic sphere.

After all, modern information technologies are a unique key to harness the public administration potential in the interest of sustainable socio-economic development of Ukraine and crisis situations prevention. State development requires the use of modern technologies and procedures that facilitate the adoption of well-motivated political, economic and social decisions in the public procurement field.

At the same time, it should be noted that, in view of national and foreign experience, the level of development and accessibility of information and communication infrastructure depends not only on the technological and technical achievements of society. Thus, although modern digital technologies create all the necessary prerequisites for a comprehensive, efficient, and innovative development of society and economy, the right to choose the vector for the development of information and communication technologies and their infrastructure still remains the exclusive state prerogative, which, unfortunately, often has political prerequisites.

Moreover, the public administration reform and the implementation of the relatively new law of Ukraine "On Public Procurement", which are currently being carried out, urge for a comprehensive and thorough analysis of public administration activities in the sphere of public procurement, including a review of administrative and legal regulation of information relations of the above entities.

\section{Definition and classification of public procurement subjects}

The public administration subjects that carry out administrative and legal regulation of information relations in the field of public procurement are, first of all, the subjects of information and legal relations that possess information legal personality, which includes two legal qualities: information legal capacity, which is the ability to have information rights and responsibilities, and information competence - the ability to acquire information rights and create responsibilities through their actions (Zaiarnyi, 2015). Exactly the very approach of understanding the content of legal personality is considered to be conventional and recognized by the vast majority of scholars.

It is also noteworthy that depending on the scope of information rights and obligations, in accordance with Article 7 of the Law of Ukraine "On Information", it is possible to distinguish general and special subjects (Law on information, 1992). General subjects of information and legal relations are the state and public administration bodies, except for the bodies with special information competence; natural and legal persons for whom information activity is not the main activity. Special entities include authorities with special information competence. Accordingly, the administrative and legal regulation of information relations in the field of public procurement (that is, relations between participants and ordering customers) is carried out by both general and special public administration subjects.

Among public administration subjects, the state as a special subject of information and legal relations plays a key role in defining information policy or in 
other words in determining the state's activity related to information obtainment, usage, dissemination, and storage. The state information policy is commonly developed and implemented by state authorities of general competence, as well as by the bodies of special competence, which also act as information relations subjects.

In general, it should be noted that the core areas of national information policy are the following: ensuring citizens access to information; creation of national information and telecommunication systems and networks; improvement of material, technical, financial, organizational, and legal bases of information activity; ensuring efficient use of information; continuous modernization and improvement of national information resources; international cooperation in the field of informatization and information sovereignty of Ukraine, etc.

Among the public authorities of general competence, the following should be outlined:

- The Verkhovna Rada of Ukraine (aimed at creating a coherent legal system to ensure the development of information and communication technologies, improvement of tax climate for businesses within the industry of information and communication technologies, creation of parliamentary information space to ensure effective interparliamentary cooperation, etc.);

- Cabinet of Ministers of Ukraine (aimed at creating proper conditions for the development of information society, the use of information and communication technologies, telecommunications, reliable information security; the use of information and communication technologies on granted access to information resources to all population segments; ensures equal and unlimited user access to telecommunications services, as well as to the creation of a central executive body that will be in charge of creating and implementing state policy of national information society);

- Administration of State Special Communications Service of Ukraine (intended to promote the conclusion of the self-regulated legal act - public agreement (memorandum) on quality standards of Internet access provision in Ukraine, its transition to international standards of information security and information security management, etc);

- The National Council of Ukraine on Television and Radio (intended to ensure maximum coverage of public broadcasting in Ukraine etc.) and others.

The special subjects (meaning those that regulate national information infrastructure as such regulation is their primary goal) do not currently include any public authorities. Furthermore, the Cabinet of Ministers of Ukraine is currently obliged to establish a central executive body that will ensure the formation or/and implementation of state policy in the sphere of information society development, information and communication technologies telecommunications and communications usage.

\section{Administrative and legal regulation of information relations of public procurement subjects}

While revealing administrative and legal regulation of information relations of public procurement subjects in the economic sphere, particular attention should be paid to the provisions of the fundamental Law of Ukraine "On Public Procurement" (Law on public procurements, 2015), which defines the range of relations that arise in the field of public procurement.

In general, relations in the public procurement field are mixed in nature, which is caused by a combination of public-law and private-law regulatory methods. This state of affairs is explained by the specificity of relations arising in the field of public procurement, which, on the one hand, are aimed at satisfying public interests and, on the other hand, are characterized by the presence of a number of private legal and regulatory mechanisms (Povydysh, 2018).

In this regard, it is necessary to mention the point of view N. Tsybulnik, who stresses that relations subject to administrative and legal regulation play a pivotal role in the public procurement sphere (Tsybulnyk, 2018). Thus, the relations arising in the public procurement sphere are primarily characterized by such features as public interest and control.

$\mathrm{K}$. Husanova, in turn, justifies the necessity of using administrative (public) legal methods within the public procurement sphere with the following circumstances:

- the procurement procedure is determined at the legislative level by respective legal acts providing for establishing prescriptions, permits, and prohibitions;

- financial regulation of trade and economic relations is a state function;

- procurement of goods, works, and services for public funds is done to meet public needs;

- regulation of public procurement relations is caused by the state's obligation to control the cash flow of state and local budgets;

- material flows management is being carried out;

- expenditures control is ensured (Khusanova, 2010).

Since the very article subject is the administrative and legal regulation of information relations of public procurement subjects in the economic sphere, particular attention should be paid to the respective group of relations.

While examining the public administration subjects in the field of public procurement, O. Yuditskyi proposes to distinguish two main groups of participants in the public procurement sphere: 1) public procurement subjects, i.e. persons who enter into public procurement procedures; 2 ) bodies that carry out state regulation and control in the procurement sphere (Yuditskyi, 2012). 
Thus, within the first group of information relations subjects, it is expedient to outline the following public procurement participants: operators of authorized electronic platforms; customers; procurement procedure participants.

As regarding the public administration subjects in the field of public procurement, the analysis of the Law of Ukraine "On Public Procurement" allows us to identify an authorized public procurement state body (in accordance with the Resolution of the Cabinet of Ministers of Ukraine "On Matters of the Ministry of Economic Development and Trade" dated 20 August 2014 No. 45 (Resolution on matters of the Ministry of Economic Development and Trade, 2014), the Ministry of Economic Development and Trade of Ukraine is such an authorised state authority), which using its powers regulates and implements state procurement policy. Accordingly, the Law of Ukraine "On Public Procurement" imposes a fairly broad list of functions upon the Ministry of Economic Development and Trade of Ukraine, which can be divided into several groups:

- regulatory support of the public procurement sphere. The Ministry of Economic Development and Trade of Ukraine is authorized to develop and approve legal acts that are crucial for the implementation of the Law of Ukraine "On Public Procurement", develop and approve forms of documents used in public procurement procedures;

- organizational, methodological, and informational support of the public procurement sphere. Such activity includes studying, summarizing and disseminating global procurement experience, running information resources of the Ministry of Economic Development and Trade of Ukraine, organizing procurement meetings and seminars, providing general policy advice on the application of procurement law, providing free consultations on the Ministry of Economic Development and Trade of Ukraine website, developing model educating programs on organizing and managing procurement, raising public awareness of existing public procurement policies and rules;

- control and analysis of the state of public procurement system functioning. Ministry of Economic Development and Trade of Ukraine is the state body that analyses the functioning of the public procurement system, generalizes procurement practice, including experience of international interaction with the public that relates to public procurement system development, cooperates with state authorities and public organizations to tackle corruption;

- ensuring proper functioning of electronic procurement system, which is an information and telecommunication system that ensures procurement procedures, creation, placement, publication, and exchange of information and documents in electronic form, which includes the web portal of the Ministry of Economic Development and Trade of Ukraine and the authorized electronic platforms among which automatic exchange of information and documents is ensured (Zakon pro publichni zakupivli, 2015). The procedure of electronic procurement system functioning is regulated by the Procedure of functioning of procurement electronic system and carrying out electronic platforms authorization, approved by the Resolution of the Cabinet of Ministers of Ukraine Decree dated 24 February 2016 No. 166 (Resolution on approving the Procedure of functioning of the electronic procurement system and carrying out electronic platforms authorization, 2016).

Another body involved in ensuring proper functioning of electronic procurement system is the specially authorized central executive body that carries out special organization of communications and information protection (according to the Law of Ukraine "On State Service of Special Communications and Information Protection of Ukraine", the State Service of Special Communications and Information Protection of Ukraine is the state body that organizes state examinations of complex information protection systems, provides examinations, and verifies proper level of technical and cryptographic data protection while authorizing electronic procurement platforms.

Along with the Ministry of Economic Development and Trade of Ukraine, a body of appeal, which is the Antimonopoly Committee of Ukraine, plays a special role in administrative and legal relations in the public procurement field. In fact, the existence of the mechanism of appeal, which is actually an extra-judicial (administrative) procedure for disputes resolution, only emphasizes the administrative and legal nature of relations arising in the public procurement field.

In addition to the procurement authority and the appeal body, the bodies responsible for regulating and controlling public procurement should include, in particular, the State Treasury Service of Ukraine, the State Audit Service of Ukraine and the Accounting Chamber (Povydysh, 2018).

Of course, the existing approach to the public procurement system organization is well-elaborated, but it is not of a systematic nature and does not take into account the constitutional provisions related to the public authorities' system. In particular, the authors stress that the determination of state regulation subjects' powers, status, and structure, as well as the formation of the national information infrastructure, in particular in the field of public procurement, should start from the provisions of the Constitution of Ukraine. Noteworthy that such a position is supported by O. Baranov, O. Oliynyk, and other researchers (Baranov, 2010).

Thus, among the subjects of state regulation and formation of the national information infrastructure, there are four organizational and structural levels. The first level of authority organization includes the Verkhovna Rada of Ukraine, the President of 
Ukraine, the Cabinet of Ministers of Ukraine, and the National Security and Defence Council of Ukraine, as a coordinating and advisory body under the President of Ukraine.

At the same time, according to O. Oliynyk, the central and local executive bodies and other state bodies carrying out special powers should be attributed to the second level of state regulation subjects (Oliinyk, 2012).

The third level of an organizational and functional system of state regulation and national information infrastructure formation includes enterprises, institutions, and organizations that are of crucial importance for the national level of the information society development, information and telecommunication technologies implementation into the social life, as well as the activities of public administration bodies.

The fourth level of organizational and functional regulation and formation of national information infrastructure should include citizens and their associations, as well as public and private media.

O. Baranov, in turn, classifies subjects of state regulation and formation of national information infrastructure by branches of power (Baranov, 2005).

Thus, according to $\mathrm{O}$. Baranov, the state bodies vested with exclusive legislative competence, in accordance with the provisions of Article 92 of the Constitution of Ukraine, only include the Verkhovna Rada of Ukraine, which is the ultimate body authorized to adopt laws, run parliamentary hearings on different information issues, etc. At the same time, a number of Verkhovna Rada committees directly deal with national information policy issues, in particular, concerning the freedom of speech and information, on transport and communication, on cultural and spiritual issues, on national security and defence.

Subjects with executive functions, according to O. Baranov, include:

1. The President of Ukraine who, in accordance with Article 106 of the Constitution of Ukraine, has exclusive powers in the information field (Constitution of Ukraine, 1996), namely the rights to: protect state independence, national security and, in particular, information security; participate in the formation of members of the Cabinet of Ministers of Ukraine; appoint and dismiss heads of local state administrations based on the respective recommendations of the Cabinet of Ministers of Ukraine; appoint and dismiss half of the members of the National Council of Ukraine for Television and Radio Broadcasting, etc.

2. The Cabinet of Ministers of Ukraine is the highest institution in the system of executive bodies. The general powers of the Cabinet of Ministers of Ukraine are set out in Article 116 of the Constitution of Ukraine while the specific powers of the Cabinet of Ministers of Ukraine in the information sphere are set out in the Law of Ukraine "On the Cabinet of Ministers of Ukraine". According to the Law, the Cabinet of Ministers of Ukraine conducts state policy in the field of informatization, promotes the creation of a single information space on the territory of Ukraine, manages the systematic implementation of advanced information and communication technologies.

3. The National Security and Defence Council of Ukraine is a coordinating body on national security and defence under the President of Ukraine, which is responsible for ensuring national information security, protection of national information resources, information and telecommunication systems and databases.

4. The State Committee on Television and Radio Broadcasting is the central executive body with a special status, which participates in the formation and implementation of state policy in the information sphere, and its activities are directed and coordinated by the Cabinet of Ministers of Ukraine. The Committee's main tasks are the formation and implementation of state policy in the fields of television and radio broadcasting, information and publishing spheres; creation of a single information space; promoting the development of information society and, in particular, the integration of modern information and communication technologies into the activities of public authorities and local selfgovernment, the development of information resources, information and telecommunication systems.

5. The National Television and Radio Broadcasting Council of Ukraine is a constitutional, permanent collegiate body whose purpose is to oversee the observance of the laws of Ukraine in the field of broadcasting, as well as the exercise of regulatory powers. The strategic importance of this body for the development of the national information society and the construction of the national information infrastructure is explained by the exclusive control and regulatory competence under which the telecommunication service entities, which, in particular, provide the public administration bodies with an adequate volume of information, communication services.

6. The National Commission for the State Regulation of Communications and Informatization. The importance of this body for the formation and development of the national information infrastructure is explained by the existing powers on implementation of state policy on national information society development and the autonomy in determining ways how to solve particular problems that arise at the national level.

7. The State Service for Special Communications and Information Protection of Ukraine participates in the formation and implementation of the state policy in the field of telecommunications and use of the radio frequency resource of Ukraine, protection of information, state information resources and information and telecommunication systems as key structural elements of the national information infrastructure. 
8. The State Agency for Electronic Governance of Ukraine is the central executive body, whose activity is directed and coordinated by the Cabinet of Ministers of Ukraine. This body, among other things, is engaged in the introduction of a new form of government based on the widespread use of modern information technologies - e-government, as well as it implements the state policy in the field of informatization, formation, and use of national electronic information resources and development of the information society.

9. The Ministry of Justice of Ukraine is a state executive body that performs state registration of print media and news agencies and is empowered, in particular, with the powers of the central certification body of the national electronic digital signature system, which is important to ensure the security of the national information infrastructure.

10. The Ministry of Economic Development and Trade of Ukraine is an authorized procurement body that provides regulatory, organizational, methodological, and legal support for the public procurement sphere, controls and analyses the functioning of the public procurement system, ensures the proper functioning of the electronic procurement system.

The above approach to classifying public administration bodies that carry out administrative and legal regulation of information relations in the public procurement field is complicated and multi-faceted. At the same time, according to the Green Paper on e-Governance and Section 2.1 of the White Paper the assessment of state organizational and managerial support of electronic interaction indicates that one of the core issues of public administration authorities, is a lack of coordination of actions between field authorities (The Working Group on the Development of governmental policies on e-Governance in Ukraine, 2014; Vyskuba, 2014). The problem solution involves institutional (structural or/and functional) changes that precede or take place simultaneously with the introduction of electronic interaction.

At the same time, the White Paper highlights two approaches to the organization of management processes that are inherent in Ukraine:

- centralized approach, which provides for the creation of a separate state authority within the executive bodies system, for instance, a ministry based on existing central executive bodies with simultaneous formation of new state bodies hierarchy and improvement of existing horizontal links, including elimination of authorities with duplicated powers, as well as integration of clarification and refinement functions into the relevant ministry line;

- decentralized (branched) approach whereby the existing distributed structure of central executive bodies, which are responsible for the development of different segments of the public procurement sphere, is enough to regulate information relations of public procurement subjects. Meanwhile, particular goals, tasks, functions, horizontal communications, and content of existing state bodies must be specified and one particular central executive body must be chosen as a key coordinator responsible for the creation and implementation of state policies on information society development and information and communication technologies improvement.

\section{Key tendencies related to administrative and legal regulation development}

A detailed analysis of the current state of the national information infrastructure shows that the main trends in the development of administrative and legal regulation of information relations of public procurement subjects in the economic sphere are the following: necessity of creating, modernizing, and integrating modern information technologies into the activity of state and municipal authorities; promotion of national technologies, information systems and telecommunication equipment produced by domestic manufacturers; further integration of international and transnational information technologies into the activity of domestic public administration bodies; organization of educational trainings for public administration bodies personnel and teaching them how to work with modern information systems and technical devices.

Noteworthy that in Ukraine there is a plethora of misconceptions and errors in procurement procedures. However, such a situation can be remedied by enhancing preventive control and further automatization of purchasing processes. Given the above, the Ministry of Economic Development and Trade of Ukraine continues implementing measures aimed at improving legislation, professionalization of public procurement, developing international relations, and ensuring the performance of functions established by the Law of Ukraine "On Public Procurement" (Report containing analysis of the public procurement system functioning and summarized information on implications of control in the procurement sphere, 2018). Indeed, it is necessary to further improve the monitoring function of the Ministry of Economic Development and Trade of Ukraine, which is an important step to further public procurement system reform. In particular, it is appropriate to establish the following types of monitoring: general (analytical) monitoring; monitoring of individual procurement procedures.

Among further development prospects of administrative and legal regulation of information relations of public procurement subjects in the economic sphere, the authors also underscore the significance of modern information and analytical support of public administration bodies activity, the necessity of organizing national electronic information resources system, creation of a new and improvement of the 
current legal framework in the sphere of informatization and harmonization of standards for IT products and IT services with EU standards, which will become a reliable precondition for creating a progressive national information society and effectively implementing electronic governance (e-government) in Ukraine.

Furthermore, attracting investments for the implementation of modern technologies and involvement of experts with managerial experience in national information resources and e-governance should also become important tendencies of developing administrative and legal regulation of information relations of public procurement subjects in the economic sphere.

\section{Conclusions}

Therefore, summing all up, it should be noted that despite the dispersion of the state authorities' system in Ukraine, the vast majority thereof in one way or another interact with national information infrastructure of Ukraine or at least with one of its structural components (information resources, information and telecommunication systems). However, as of now, the existing system of Ukrainian central bodies with executive powers still lack a special body, whose competence would encompass complex regulation of public relations arising in the sphere of information and communication development, communication technologies, national information space, information society, and the national information infrastructure as a proper legal platform for information relations among public administration bodies.

As a result, the functions related to the use of information and communication technologies are entrusted to the authorities of general competence, wherein the relevant information and communication powers are subsidiary and additional in nature, and therefore, they cannot be systematically and comprehensively regulated.

Such a legal loophole has a surprisingly negative impact on the activities of public administration since it, on the one hand, deprives the authorities and their officials of the opportunity to make full and comprehensive use of existing technological capabilities in the world and, on the other hand, limits the opportunities of citizens in their interaction with public (state and municipal) authorities.

Thus, the above indicates that the existing national legislation related to administrative and legal regulation of information relations of public procurement entities in the economic sphere is insufficient, and currently we are still at the stage of legislative definition of basic concepts and their structural elements. At the same time, the increasing number of scientific works devoted to the study of the above issue clearly indicates the expressed interest of the scientific community and society as a whole in implementing foreign experience in the formation, implementation, and development of national information infrastructure.

\section{References:}

Zaiarnyi, O. A. (2015). Subiekt administratyvnykh informatsiinykh pravoporushen: poniattia ta osoblyvosti [The subject of administrative information offenses: concepts and features]. Administrative Law and Process, 2(12), 86-104. (in Ukrainian)

Zakon pro informatsiiu (1992). [Law on information]. Ofitsiynyy sayt Verkhovnoyi Rady Ukrayiny. [The official website of the Verkhovna Rada of Ukraine]. Retrieved from: http://zakon2.rada.gov.ua/laws/show/2657-12 (accessed August 03, 2019). (in Ukrainian)

Zakon pro publichni zakupivli (2015). [Law on public procurements]. Retrieved from: https://zakon.rada.gov.ua/ laws/show/922-19 (accessed August 03, 2019). (in Ukrainian)

Povydysh, V. V. (2018). Administratyvno-pravovi vidnosyny u sferi elektronnykh publichnykh zakupivel [Administrative and legal relations in the sphere of electronic public procurement]. Naukovyi visnyk publichnoho ta pryvatnoho prava, 6, 87-93. (in Ukrainian)

Tsybulnyk, N. Y. (2018). Administratyvno-pravove zabezpechennia publichnykh zakupivel v Ukraini [Administrative and legal support of public procurement in Ukraine] (PhD Thesis). Zaporizhzhia: Zaporizhzhia National University. (in Ukrainian)

Khusanova, K. Y. (2010). Do pytannia pro osoblyvosti metodu pravovoho rehuliuvannia vidnosyn u sferi derzhavnykh zakupivel [On the peculiarities of the method of legal regulation of relations in the field of public procurement]. Chasopys Kyivskoho universytetu prava, 1, 117-124. (in Ukrainian)

Yuditskyi, O. L. (2012). Vydy ta problemy pravovoho stanovyshcha subiektiv derzhavnykh zakupivel [Types and Problems of Legal Status of Public Procurement Subjects]. Chasopys Kyivskoho universytetu prava, 2, $242-247$. (in Ukrainian)

Postanova pro pytannia Ministerstva ekonomichnoho rozvytku i torhivli (2014). [Resolution on matters of the Ministry of Economic Development and Trade]. Retrieved from: https://zakon3.rada.gov.ua/laws/show/ 459-2014-\%D0\%BF (accessed August 03, 2019). (in Ukrainian)

Postanova pro zatverdzhennia Poriadku funktsionuvannia elektronnoi systemy zakupivel ta provedennia avtoryzatsii elektronnykh maidanchykiv (2016). [Resolution on approving the Procedure of functioning of the electronic procurement system and carrying out electronic platforms]. Retrieved from: https://zakon.rada.gov.ua/ laws/show/166-2016-п/print (accessed August 03, 2019). (in Ukrainian) 
Baranov, O. A. (2005). Informatsiine pravo Ukrainy: stan, problemy, perspektyvy [Information Law of Ukraine: State, Problems, Prospects]. Kyiv: Soft Press. (in Ukrainian)

Oliinyk, O. V. (2012). Struktura subiektiv zabezpechennia informatsiinoi bezpeky v Ukraini [Structure of information security subjects in Ukraine]. Aktualni problemy derzhavy i prava, 68, 110-117. (in Ukrainian)

Konstytutsiia Ukrainy (1996). [Constitution of Ukraine]. Retrieved from: https://zakon.rada.gov.ua/laws/ show/254к/96-вр (accessed August 03, 2019). (in Ukrainian)

Robocha hrupa z rozrobky uriadovoi polityky u sferi rozvytku elektronnoho uriaduvannia Ukrainy (2014). [The Working Group on the Development of governmental policies on e-Governance in Ukraine]. Proekt do obhovorennia: zelena knyha $z$ elektronnoho uriaduvannia $v$ Ukraini. Retrieved from: http://etransformation.org.ua/ 2014/11/17/318 (accessed August 03, 2019). (in Ukrainian)

Vyskuba, O. (ed.) (2014). Proekt do obhovorennia: zelena knyha z elektronnoho uriaduvannia v Ukraini [Electronic Interaction. White Paper on Public Policy]. Kyiv - Dnipropetrovsk. (in Ukrainian)

Ministerstvo ekonomichnoho rozvytku i torhivli (2018). Zvit, shcho mistyt analiz funktsionuvannia systemy publichnykh zakupivel ta uzahalnenu informatsiiu pro rezultaty zdiisnennia kontroliu u sferi zakupivel [Report containing analysis of the public procurement system functioning and summarized information on implications of control in the procurement sphere]. Kyiv: Ministry of Economic Development and Trade. (in Ukrainian) 